\title{
7. Peas, beans and riverbanks: seasonal picking and dependence in the Tuross Valley
}

\author{
JOHN WHITE
}

The Tuross River Valley is one of six major estuarine systems along the South Coast region of New South Wales. Today, the valley falls within the boundaries of the Eurobodalla Shire. The Yuin people are acknowledged as the traditional owners and custodians of the region. The township of Bodalla is located on the northern elbow of the Tuross River and the major nearby towns are Moruya in the north and Narooma to the south. While Bodalla achieved renown as a major dairying centre in the late nineteenth century, the forestry and horticultural industries have also made significant contributions to its economic development. The important roles that Aboriginal people have played in the expansion of the rural economy have, however, been largely neglected in the local histories of the South Coast. This chapter is part of a broader effort aimed at correcting the lack of acknowledgment of the contribution of Aboriginal labour to the local economy and, more generally, in the wider Australian context. The Tuross River farms at the 'back of Bodalla' hold vivid memories for present-day Aboriginal people living in the Eurobodalla Shire, many of whom spent much of their childhood years in and around the bean and pea fields. Bean and pea production began in the valley in the 1930s and provided work for Aboriginal people through to the constriction of the industry in the 1970s. The oral history record confirms that the majority of pickers were Aboriginal people, with South Coast families being joined in the picking fields by itinerant workers at the height of the season due to the large labour force needed to ensure that crops were picked in the best condition. ${ }^{1}$

Studies by Bell (1955) and Castle and Hagan (1978) have documented the relationship between Aboriginal people and the economy of the South Coast during the mid to late twentieth century. Both studies conclude that Aboriginal

1 This chapter draws on three publications arising through the Eurobodalla Aboriginal Cultural Heritage Study. For an extensive study of Aboriginal history in the region, see Goulding and Waters (2005). For oral accounts relating to cultural heritage, see Dale Donaldson $(2006,2008)$. 
people were dependent either on the employment offered by settler society or on hand-outs and rations provided by the state. At first glance, the use of the word 'dependent' appears to mean a state of reliance by Aboriginal people on settler society for the means of survival. The notion sits within a more pervasive trope, however, which questions the viability of heterogeneous social and economic forms in Aboriginal communities. In 1951, A. P. Elkin outlined what he considered to be culturally determined stages relating to the response of Aboriginal people to white settlement along a continuum ranging from a precolonial stasis to full assimilation (Elkin 1951). Elkin's notion of assimilation was based on the total adoption of white culture by Aboriginal people and was influential in shaping the terms of reference used in both anthropological and broader public discourse during the debates of the time. ${ }^{2}$ As part of a longer legacy, this paradigm heavily informed Bell's study of the economic conditions of 'mixed-blood' Aboriginal people between Port Kembla and the Victorian border along the South Coast of New South Wales. Bell (1955:186) identified the importance of seasonal picking to the livelihood of Aboriginal people in the Bodalla and Bega districts and described the level of their involvement in the horticultural industry as being a 'monopoly'. Interestingly, Bell (1955:198) concluded that this pattern of employment illustrates 'the lack of any successful economic assimilation...into the general Australian economic system, and, hence, their economic dependence upon the white community'. Aboriginal involvement in seasonal work (as opposed to continuous employment) was seen as lacking the kind of syncretism espoused by Elkin and, therein, impeding the process of assimilation.

In a later study, Castle and Hagan also trace the rise of Aboriginal involvement in the picking industry of the Bega Valley and conclude that engagement in the sector situated Aboriginal people in a position of structural dependence that, through processes of industry decline and increasing involvement in the political sphere, presaged a transition to 'independence' in the mid-1970s (Castle and Hagan 1978). This cycle, they argue, was constituted by an annual oscillation between seasonal picking and what Elkin (1951) classed 'intelligent parasitism'. While stating that the resident Aboriginal families were descendents of a dispossessed and displaced people whose 'former way of life had since then become impossible', and whose 'customs and law had broken down', the idea that assimilation had failed is not explicated (Castle and Hagan 1978:159). Castle and Hagan argue that by the 1920s only a very small proportion of Aboriginal people were engaged in the workforce and even less had consistent contact with the cash economy. This pattern is presented as being continuous through to the

2 For an examination of the assimilation policy debates between Elkin, Strehlow and Hasluck, see McGregor (2002). 
1960s and caused in part by the policies of the Aborigines Protection Board (and its successor, the Aborigines Welfare Board). Castle and Hagan's understandings of this period are clearly presented in the following passage:

In all aspects of life they were subject to white authority. They were socially segregated and dependent for their welfare on white charity and benevolence. They accepted these relationships. There was among them no movement to change or alter the world in which they found themselves. If they had a consciousness of themselves as Aborigines, then it was a fatalistic one which held that what had occurred was inevitable, and that the future could bring no change. Those of them who were Christians knew of the Ten Tribes of Noah. For them, salvation came in the next world. For the unregenerate, there was no hope. (Castle and Hagan 1978:164)

According to this reasoning, regardless of whether Aboriginal people were engaged in wage-labour relationships or not, the failure of assimilation through the perceived inability of Aboriginal people to blend into the broader social and economic milieu established a mire of hopelessness and dependence. The transition to 'independence' in the 1970s, brought about through processes of industry decline, increasing political agency for Aboriginal people, greater provision of town housing and broadening employment opportunities, could then be rationalised as successful cultural syncretism (and hence, successful assimilation).

While converging on the same conclusion of dependence, neither Bell nor Castle and Hagan pays attention to the non-monetised value of resource use for Aboriginal people working in seasonal employment. The continuation and reconstitution of a fishing tradition among South Coast Aboriginal people remain defining aspects of Yuin identity today, and (in terms of providing an independent avenue for economic activity) should be addressed in a reexamination of twentieth-century seasonal picking. Moreover, neither study acknowledges the long record of engagement between Aboriginal people and the expanding settler economy. I argue that the use of the notion of 'dependence' (as unsuccessful assimilation) obfuscates the innovative and socially meaningful ways in which Aboriginal people interact with the economy. In light of these two studies, this chapter aims to trace the historical trajectory of settler colonialism and governmental control in the Tuross Valley and its surrounds, detailing the rise of Aboriginal engagement with the picking industry, and will conclude by make some comments on the usefulness of the term 'dependence' in this historical context. 


\section{Expansion of colonial capitalism}

Congruent with the experiences of Indigenous communities throughout southeastern Australia, the expansion of colonial capitalism on the South Coast of New South Wales was accompanied by increases in governmental intervention in the process of colonisation, particularly the exercise of control over its original population through the use of rationing, surveillance and institutionalisation (see Morris 1989; Rowse 1998). In contrast with the establishment of Christian missions in other parts of Australia, the station at Wallaga Lake on the NSW South Coast was a secular, government-run institution. The creation of the stations (and the Aborigines Protection Board for that matter) was part of a concerted effort by the state to contain the situation that had arisen through the initial period of colonisation. As Long (1970:26) notes: 'Government activity until 1881 had been confined to desultory efforts to moderate conflict with the nomadic Aborigines as the frontier of White settlement expanded and then to mitigate the effects of contact on the Aborigines within the limits of settlement.' While it was assumed that increasing state intervention would help to reduce frontier violence, the need to 'mitigate the effects of contact' was underlined by conservative racial discourses that demanded that the state control and 'civilise' Aboriginal people both within the limits of settlement and elsewhere on the frontier.

The formalisation of administrative control over Aboriginal people in New South Wales can be traced to the concerns of missionaries regarding the vulnerability and penury of Aboriginal people who had survived the initial invasion. Prominent missionary figures argued that renewed effort should be given to the 'task of civilisation' or, in the words of the Reverend J. B. Gribble, 'to wipe out that long-standing disgrace, viz. the unjustifiable neglect of the heathen in our midst' (cited in Long 1970:26). The successful petitioning of the church led to the establishment of missions at Maloga on the Murray River in 1874 and Warangesda on the Murrumbidgee River in 1880. Linked to Gribble's concerns was a second, secular rationale, described by Morris (1989:90) as a desire to render Aboriginal people governable by reducing them 'to the status of colonial wards'. The aspiration of missionaries to protect (and indoctrinate) Aboriginal people was translated into legalistic custodianship on the creation of the office of Protector of Aborigines in 1880 (Morris 1989:90). In 1881, the colonial administration appointed George Thornton as Protector of Aborigines, whose initial charge was to commission a comprehensive enumeration and survey of the condition of Aboriginal people throughout the state.

Thornton's preliminary conclusion was that assistance should be given only to Aboriginal people living on-country and he argued that all efforts should be made to prevent their presence 'about the metropolis' (Long 1970:27). As Morris 
notes, the rationale behind this move was twofold. First, it was hoped that communities would be largely self-sufficient with the provision of opportunities for collective agricultural cultivation. Second, according to the 'commonsense' view that Aboriginal people were going to disappear entirely, the creation of reserves as segregated havens away from the rigours and confusions of settler society was thought to have provided 'the soothing pillow of a dying race' (Morris 1985:93-4). In an assessment that must have frustrated Gribble and his contemporaries, Thornton also concluded that secular administration would be far more effective than religious instruction, and urged that young Aboriginal people should be taught manual skills appropriate for entry into the colonial workforce (Long 1970:27). Soon after, in 1883, a Board for the Protection of the Aborigines was appointed under the direction of Thornton, though it lacked the legislative muscle needed to control the movement of Aboriginal people. The first station in New South Wales was created when the board reserved a portion of land at Wallaga Lake for the use of Aboriginal people in 1891. In 1909, the Aborigines Protection Act was passed, granting the board the powers it needed to segregate the Aboriginal population. The location of the Wallaga Lake station- $16 \mathrm{~km}$ from Bermagui, $24 \mathrm{~km}$ from Narooma, 40km from Bodalla and $64 \mathrm{~km}$ from Bega - was ideally placed to suit the board's goal of isolating Aboriginal people from the regional centres (Long 1970:62). The Act was, as Morris (1989:90) argues, 'the pivotal point... which prefigured a change in the nature of control over Aboriginal communities in the latter decades'.

\section{Early engagement with the settler economy}

Chris Lloyd's chapter in this volume argues that a critical determinant of economic growth in the Australian settler economy was the availability of labour. In the case of the Eurobodalla region, the evidence suggests that the shortage of available labour was alleviated to some degree by the incorporation of Indigenous workers during the initial period of economic expansion and diversification in the settler economy. By the time the board had passed the 1909 Act, Aboriginal people on the South Coast had already been actively engaged with the settler economy for at least 70 years. Aside from early records documenting the involvement of Aboriginal people in the whaling industry at Twofold Bay, several sources provide evidence of Indigenous labour with the initial European settlers in the Eurobodalla region (Brierly 1842-43, 1842-48, 1844-51). One of the earliest written records identifying individual Aboriginal workers was by John Hawdon, who, along with Francis Flanagan, had taken up land in the Moruya area by 1830. In one of his letters, Hawdon refers to an Aboriginal man known as Benson as a 'faithful servant for many years'. He refers to two other men called Campbell and Walker in a similar way. On the advice 
of Aboriginal people who showed him the location of 'good grass and water', Hawdon later expanded his landholdings to include parcels in the Bodalla area (Buck n.d.). Further north at Broulee, Flanagan observed:

Those who choose to work can obtain plenty of food and clothing, and they seldom have of necessity to depend upon fishing or hunting for subsistence... Both males and females are employed by the settlers in gathering the maize and potatoe crop, and some of them in reaping. They have commonly been remunerated in provisions, clothes, tea, sugar, tobacco, \&c., but many of them now insist upon being paid in money. They are always employed for stripping bark... They will only work when the fancy seizes them, and always go off without warning. (Flanagan 1845; see also Gibson, this volume on attitudes to employment)

After less than a decade of contact with the first settlers, Aboriginal people in the Eurobodalla region were already engaged in reciprocal relationships of labour and in-kind or cash payment. Their extensive knowledge of the coastal hinterlands and the correct timing for stripping bark made them valuable to the tanning industry. Wattle bark was the first legume cash crop in Australia and provided an extract used for tanning throughout the colonies. By 1823, the tannin yielded from the bark-stripping labour of 'bush workers' was being shipped to Britain (Davidson and Davidson 1993:215). It appears that transactions were taking place on a negotiated, contract basis, as a journalist's account of a journey along the South Coast in 1871 implies:

About five miles from Moruya we met a blackfellow carrying a long straight stick. He recognized Mr Flanagan with a grin, and pointed to the notches - about forty in number - quite triumphantly. On enquiry I discovered that the blackfellow is employed bark-stripping, and gets so much per sheet, for all he strips. The notched stick was his account of the number of sheets. (Anon. 1871)

These relationships were, to some extent, forged through hardships experienced by the early settlers and kindness on the part of Aboriginal people. While violence was common on the frontier, as Goulding and Waters (2005:37) note, 'conflict between Aboriginal people and Europeans in the early period of European intrusion into an area is only one part of the story'. For example, Mrs Celia Rose, who arrived in Moruya as a young child in the early 1830s, recorded the local Aboriginal people providing food to the settlers: 'There was only one sailing vessel...that called at Broulee about once a month, bringing provisions from Sydney, and the shortage was at times acute. Aboriginals saved the settlement several times from starvation by supplying fish and oysters' (Rose 1923). A similar encounter occurred in 1841 when several Aboriginal men swam 
out into rough seas and rescued the survivors of the wrecked schooner Rover. Soon after, gorgets (or brass plates) were presented to the men in recognition and reward for their efforts (Oldrey 1842).

The Commissioner for Crown Lands, John Lambie, recorded European farmers in 1845 being assisted by Aboriginal labourers in a range of activities, with labour being rewarded with food and clothing (Lambie 1846). Lambie (1851) lamented that the Aboriginal workers could not be depended on, but were 'well treated, and well paid by those who employ them'. Lambie's replacement, Commissioner Manning, contradicted Lambie's observation, stating that 'quiet and orderly in their deportment, when not ill used, they are willing to labour for wages so small that their services are in general demand' (Manning 1852). While the reason for this discrepancy is unclear, Manning's observation resonates with the historical record of the use of Aboriginal labour throughout the nineteenth century. ${ }^{3}$ Importantly, as Goulding and Waters (2005:41) point out, Manning realised that Aboriginal people were motivated to work for the settlers on a seasonal basis, preferring to wander off in warmer months when resources were plentiful along the coast. Clearly, Aboriginal people had been able to successfully modify their pre-existing patterns to their changing economic circumstances and incorporate the presence of Europeans into their seasonal movements (see Cameron 1987; Organ 1990; Rose 1990). Further, as Cane (1992:8) remarks, the exchange of material goods and services between Aboriginal people and settlers 'is probably consistent with traditional methods of reciprocal exchange and could be readily incorporated into the new Aboriginal economy'. Similarly, Cameron's (1987) examination of the documentary record relating to South Coast Aboriginal people in the nineteenth century implies socioeconomic transformation, arguing that both customary and newly acquired skills enabled Aboriginal people to carve an important, though undervalued, place in the regional economy.

Following incremental changes to legislation between 1861 and 1905 designed to open up the large pastoral leases to small selectors, Aboriginal people along the South Coast were increasingly forced off their country (Goulding and Waters 2005:48). Prior to land being rapidly taken up in smaller allotments in the Tuross Valley (and vast networks of post and wire fencing being laid to delineate boundaries of title), there was still scope for the purchase of large estates. In 1860, Thomas Mort purchased more than 13000 acres (5300 ha) at Bodalla and shortly after added another 4000 acres (1600 ha) for the Comerang farm. Mort's vision was to create an integrated, privately owned estate and included the construction of a general store, bakery, butchery, hotel and blacksmith's workshop (Whiteford 1985:14). This period of rapid dispossession and displacement of Aboriginal communities on the South Coast gave rise to a range of initial responses on the part of Aboriginal people. Some travelled

3 For a regional comparison, see Bennett (2003). 
hundreds of kilometres to Sydney to petition for land, boats and fishing rights while camping at Port Jackson (Goodall 1996:75). Others fought for land to be reserved through correspondence with the Aborigines Protection Board. Close to Bodalla, 'Permissive Occupancies' that had been granted to three Aboriginal men in 1872 were gazetted as Aboriginal reserves in 1878 (Goodall 1996:79). Other Aboriginal people continued to live in camps in the vicinity of Wallaga Lake until the station was established in 1891 (Anon. 1879). The location of these camps and reserves was important in enabling the continuation of connections to the estuarine and marine environments and the maintenance and transformation of customary fishing practices (see Cane 1992; Cruze et al. 2005; Goodall 1982).

\section{Aborigines Protection Act 1909: transitions in socioeconomic conditions}

As the legislation laid down in the Aborigines Protection Act was being rolled out across the state, the intensity of state intervention into the lives of Aboriginal people at Wallaga Lake increased dramatically. It was understood that all adult men who were fit to work should leave the station to find employment or risk penalty under the 'work test' regulation in the Act, although this pattern appears already to have been established. In 1903, H. M. Trenchard was sent by the Aborigines Protection Board to inspect the conditions at Wallaga Lake and he reported that:

The young men on the Station are not encouraged to remain on the Station, and they are able to obtain suitable employment at certain times of the year at the farms in the district, and from one of the Managers' monthly reports it appeared that forty-seven men from the Station were engaged in work of various kinds off the Station, earning from 15s. to 30s. per week. (Trenchard 1904)

On a return visit seven years later, Trenchard wrote:

The people appear fairly contented, and not doing too badly in spite of bad accommodation, the numbers on the Station being much reduced in consequence of there being plenty of work obtainable, and fear of possible action by the Board under the new Act, which has been much exaggerated...It was made very plain to the residents that in future, men must work or leave the Station. (Trenchard 1911)

Another aspect of the Act had profound impacts on the stability of family life for Aboriginal people throughout New South Wales. The Act provided the board 
legal sanction to remove Aboriginal children from their families - a situation exacerbated by increasing powers being granted by way of the 1915 amendment. The process of 'apprenticing' Aboriginal children, as Goodall (1990) argues, 'sought systematically to remove as many Aboriginal children as possible and never to allow them to return to their communities'. This shift in emphasis from segregation to assimilation was in essence a policy of dispersal with the aim of breaking up family groups (Read 1982). The constant movement of Aboriginal families brought about by successive governmental interventions prescribing where and how they should live also, however, broadened the geographic range of kinship networks throughout the South Coast region of New South Wales.

The rise of the manufacturing industry following the application of the protective tariff of 1908 brought it into direct competition for labour with primary producers. The tariff stipulated that the manufacturing industry was required to pay 'fair and reasonable wages'. In the words of The Bodalla Company's director in 1912, the protective tariff had 'drawn a large proportion of the labour required in the country into the towns' (Whiteford 1985:17). The labour shortage, which had hamstrung the expansion of the primary sector, was alleviated to some degree by the 'work test' stipulations of the Aborigines Protection Act, even though the legislative aim (in terms of revenue) was reducing the cost of government rations. While there were Aboriginal milkmen working at Wallaga Lake, there is little evidence to suggest that Aboriginal people were similarly employed in the Tuross Valley, reflecting what Morris (1985:99) describes as segmented employment patterns based on an ideology of pollution'. Aside from labour devoted to 'improving the land', Aboriginal people were not widely employed by dairying producers in the region. Racialised divisions of labour were consistent with the policies of the board that sought to 'train the Aborigines and make them fit for gradual assimilation' (Long 1970:31). Divisions of labour also occurred along gendered lines within this schema: Aboriginal girls were apprenticed and trained as domestic maids or servants while Aboriginal boys were taught skills appropriate for labourers, farmhands or timber workers. As Goodall (1990) notes, the removal and training of Aboriginal children were a complex 'interaction between prevailing anxieties about race and gender, labour market needs and pre-existing administrative precedents'. As such, the policy of assimilation was not intended to produce an egalitarian outcome but, rather, a socially stratified one that conformed to the conservative discourses of the time.

Racial attitudes were manifested not only in stratifying the type of work available to Aboriginal people, but also in competition for lower-paying jobs and through contestations over land. The end of World War I resulted in pressure being placed on the Protection Board to revoke reserved land for the use of returned servicemen. As Cane (1992:11) notes, by 1926, 75 per cent 
of reserved land in the state had been revoked, including the revocation of two reserves at Bodalla in 1920. As Goodall (1982:227) describes, however, the major pressure on Aboriginal communities living on reserves was from town expansion, with the viability of several reserves being disputed for residential development. Contestations over reserved land were followed by the Great Depression of the 1930s, which impacted heavily on the lives of Aboriginal people. This is reflected by a 200 per cent increase in the number of people living at the Wallaga Lake station between 1921 and 1939 (Long 1970:62). After hitting rock bottom in 1932, the employment situation slowly improved. Long (1970:31) notes that World War II created a labour shortage, rapidly reducing the unemployment rate of Aboriginal people in reserves from 36 per cent in 1940 to less than 4 per cent by 1944. The unemployment rate for mainstream Australia then stabilised, and between 1945 and 1974, it fluctuated about an average of 2 per cent (Commonwealth of Australia 2005). The return of servicemen after the war combined with the economic recovery to create a highly competitive labour market in which Aboriginal people were consistently relegated to lower-paying jobs.

World War II also caused a rise in the production of beans and peas, which nearly doubled to meet the demands of the armed forces (Davidson and Davidson 1993:351). In the Tuross River Valley, more than 15 farms diversified to include the production of legume cash crops. The farms at the 'back of Bodalla' were mostly family-owned operations, with the exception of The Bodalla Company (formed after Thomas Mort's death in 1879), which had also included horticultural acreage. The Bodalla Company kept fastidious records of payments made to individual bean and pea pickers between July 1959 and June 1962, corresponding with three financial years or growing seasons. The picking season began in the Tuross Valley in October and ran until March, and farmers would want to get two picks off the crop during each season. The following reminiscence of a local farmer gives a good indication of the nature of the industry:

After planting the beans or peas on the rich river flats in Eurobodalla or Cadgee...there was a lot of labour involved later in picking the fresh crop, usually only a first or second pick...A number of Aboriginal people were always employed during the picking season. A good strong back was needed and a fast picker would pick up to 8 bags of beans in a day (80lbs per bag)...It was important to work the long hours otherwise the crop would spoil with beans becoming too old and stringy. ( $\mathrm{O}^{\prime}$ Toole 1997:30)

Importantly, The Bodalla Company's wage cards show that picking work was not always continuous, but rather it involved targeted increases in labour in order to harvest the crops in the best condition. Further, as Figure 7.1 illustrates, the 
availability of work was not consistent for each growing season. Depending largely on climatic conditions, the variability in crop production was erratic and workers employed in picking therefore needed to be highly flexible about when and where their labour would be required. (While the oral record illustrates that other farms paid regularly on Saturdays, there is no evidence suggesting that this was regularly the case on The Bodalla Company farm.)

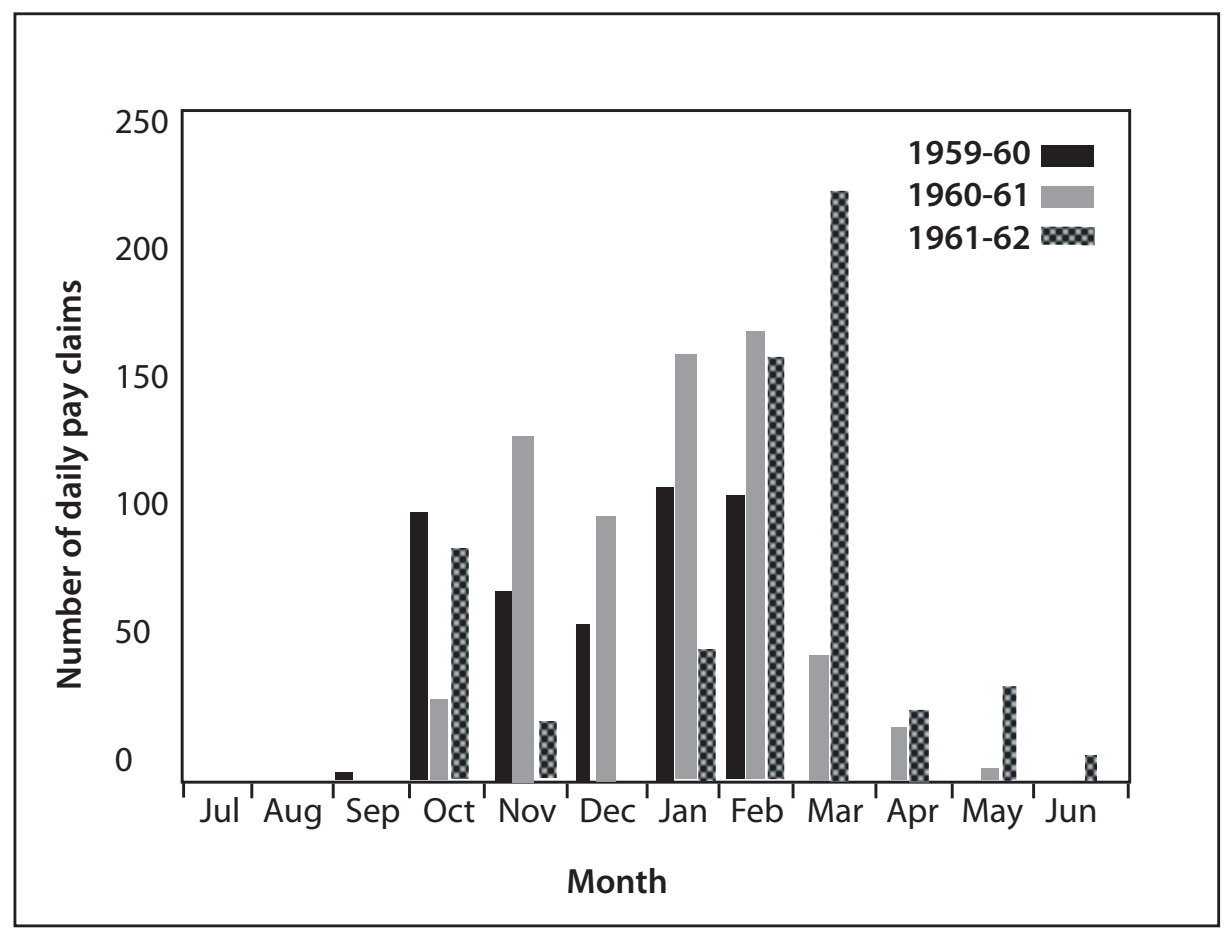

Figure 7.1 Number of pay claims per month for bean and pea picking, The Bodalla Company, 1959-60

Source: The Bodalla Company, Wages and summary cards for bean and pea picking, 1958-62.

In 1961, the Aborigines Advancement League conducted a survey of the living and working conditions of Aboriginal people in the South Coast region. At a property near Eurobodalla they noted that pickers were allowed to stay on the farm permanently and that the people are quite pleased with relations with their employer' (Anon. 1961). This pattern is consistent with oral accounts of picking life, in which Aboriginal families were welcome to live in farm sheds or to set up camps on the properties so that they could work when required. In many cases, men were holding down continuous employment in the nearby sawmills while women and children would work together in the picking fields. Many families from Wallaga Lake moved over to the Tuross Valley temporarily during the picking season. Others who continued to live on the station were 
rounded up by farmers who needed labour and ferried to and from the Tuross Valley on the back of trucks. The Bodalla Company wage cards show clustering around family names and illustrate that whole families were working together when their labour was needed. As Dale Donaldson (2006:84) remarks, 'picking work was hard work, but paid off because a lot of time was spent amongst one's family'. The condition of mainstream 'full employment' that existed throughout this period also drew hundreds of itinerant Aboriginal workers to the Tuross Valley looking for work during the picking season. The banks of the Tuross River were the sites of temporary camps for travelling seasonal pickers and local families alike. While most itinerant workers moved on at the end of the main season, some stayed and made strong connections to the Eurobodalla region that last through to the present day.

\section{Conclusions: critique of the notion of dependence}

Through this brief examination of the historical record, it is clear that the expansion of the settler economy was concurrent with governmental intervention into the lives of Aboriginal people. Early engagement with the settler economy was characterised by the transformation of existing social and economic practices and an independent and viable economy based primarily on fishing. Contra to Castle and Hagan's (1998:25) argument that 'Aboriginal people neither sought nor were given the opportunity to adapt to or participate in the white economy', the archival record on the NSW South Coast points to the active participation of Aboriginal people accompanied by rapid transformations to incorporate the settler economy into pre-existing practices and seasonal movements. Through the post-frontier period, this engagement was characterised by seasonality and constrained by government policy prescribing where and how Aboriginal people should live. The policies of assimilation, while initially aimed at breaking up Aboriginal intra and trans-familial groups, also sought to create a racially stratified underclass that preserved the status quo. These policies were accompanied by extremely low mainstream unemployment after World War II in which Aboriginal people filled a structural niche in low-paying jobs. Bean and pea production involved heavy manual labour with poor working conditions, but was a desirable alternative for people because it enabled families to work together. In light of the historical record, I will now discuss some aspects of the use of the term 'dependent' in previous studies to describe Aboriginal bean and pea pickers.

The studies by Bell (1955) and Castle and Hagan (1978) both neglect the importance of economic activities occurring outside the paradigmatic 'real' 
economy, thus placing the emphasis on the role of employers as 'patrons' and on the welfare state. Bennett's recent study of Aboriginal responses to the colonial economy in the Shoalhaven and Illawarra regions of New South Wales between 1770 and 1900 concluded that Aboriginal people maintained 'a viable and independent economy in articulation with an expanding capitalist economy' (Bennett 2003:270). Throughout the post-frontier period, Aboriginal people lived what Cane (1992:12) describes as a 'difficult and precarious socioeconomic existence' and consistently turned to fishing as an avenue for selfsufficiency. The success of Aboriginal fishers also drew them into conflict with white fishermen, reaffirming conservative racial delineations. As Goodall notes:

While employment opportunities for Guris [Kooris] were remarkably more limited on the south coast than in the other regions, Guris' selfsufficiency was enhanced not only by subsistence fishing but by fishing for the market, at which they were successful enough to cause local fishermen to protest to the Protection Board through the Fisheries Department in 1914 and 1918. (Goodall 1982:115)

As an opportunity for self-sufficiency, fishing also provided an avenue for a certain kind of autonomy - one that has been eroded by the successive revocations of reserves and increasing restrictions placed on Aboriginal fishers through the regulation of commercial and recreational fishing. The oral history record describes fishing activities as being an important aspect of seasonal work, with families setting up temporary camp at nearby beaches and estuaries when they were not needed in the picking fields. Fishing also provided a vital means of subsistence for Aboriginal people who were camped on the banks of the Tuross River when picking was on. Rather than describing the involvement of Aboriginal people in the horticultural industry in terms of a seasonal work cycle sustained by 'intelligent parasitism', it would be more appropriate to see picking work and fishing in terms of seasonal responses to changing economic circumstances. Thus, the record suggests that historical engagements between Aboriginal people and the settler economy have been mutually constituted as a result of complex historical processes.

Reflecting a broader trend in Aboriginal studies throughout much of the twentieth century, the term 'dependency' has been used ubiquitously to describe the economic status of Aboriginal people living on the South Coast to such an extent that it has obscured the importance of Indigenous contributions to the region's economic development. Bell's (1955) study concluded that South Coast Aboriginal people were dependent on either the employment offered by the white population or the financial assistance provided by the government. This conclusion was supported in Castle and Hagan's (1978:163) study in the Bega Valley, where bean picking and pea picking were rendered as dependent 
activities. The conflation of seasonal employment with a state of dependence is inappropriate given that the horticultural industry was largely dependent on Aboriginal labour. In Bell's words:

Seasonal work (crop picking) claims the largest number of Aborigines engaged in primary production, with casual work on dairy farms and in grazing, forestry and fishing completing the picture. Accustomed down through the years to performing seasonal work, the South Coast Aborigines now consider it their chief occupation. Indeed, they have a monopoly. Whites do not offer for it, partly because it is identified with the Aborigines, and partly because it is temporary. (Bell 1955:186)

The reasons for the decline of seasonal horticulture on the South Coast in the 1970s are also pertinent here. Some people cite increasing mechanisation and competition in bean and pea production from farmers in Queensland and New Zealand driving down prices and making manual, cool-climate horticulture simply unsustainable. Others point to changes in the Aboriginal workforce (Castle and Hagan 1978:167). Increases in the political agency of Aboriginal people throughout New South Wales resulted in more and more strikes and walk-offs due to poor pay rates and labour conditions. Moreover, increasing opportunities for regular employment accompanied by the greater provision of both town housing and welfare benefits meant that Aboriginal people had a broader range of options available to them. In all likelihood, the decline of seasonal horticulture on the South Coast was a combination of these two factors, which, nevertheless, highlights the importance of Aboriginal labour to the sector. In the case of the South Coast, the interdependence that existed between Tuross Valley farmers and seasonal pickers has been subsumed under a racially motivated delineation between the structural position of Aboriginal workers and their non-Indigenous counterparts. An Aboriginal worker's employer was a patron; a whitefella's employer was simply their boss.

\section{References}

Anon. 1871, 'A tour to the south: from our special correspondent: no. 10 - the Broulee district (continued)', Town and Country Journal, 7 October 1871, pp. $522-3$

Anon. 1879, 'The Tilba Tilba district', Bega Standard, 29 November 1879, p. 2.

Anon. 1961, Aborigines Advancement League: Survey into living and social conditions of Aboriginal people from Wollongong to the Victorian border, South Coast Labour Council, Wollongong, NSW. 
Bell, J. H. 1955, 'The economic life of mixed-blood Aborigines on the South Coast of New South Wales', Oceania, vol. 26, p. 181.

Bennett, M. 2003, For a labourer worthy of his hire: Aboriginal economic responses to colonisation in the Shoalhaven and Illawarra, 1770-1900, Unpublished PhD thesis, University of Canberra, ACT.

Brierly, O. 1842-43, Journal of a visit to Twofold Bay, Dec. 1842 - Jan. 1843, Mitchell Library, Sydney.

Brierly, O. 1842-48, Diaries at Twofold Bay and Sydney, Mitchell Library, Sydney.

Brierly, O. 1844-51, Reminiscences of the sea: about whales, Mitchell Library, Sydney.

Buck, M. n.d., Old Colony Days: John Hawdon's letters. Volume II, Moruya and District Historical Society, NSW.

Cameron, S. 1987, An investigation of the history of the Aborigines of the far South Coast of New South Wales in the nineteenth century, Unpublished B. Letters thesis, The Australian National University, Canberra.

Cane, S. 1992, Aboriginal fishing on the South Coast of New South Wales: a report to Blake, Dawson and Waldron and the NSW Aboriginal Land Council, Unpublished typescript.

Castle, R. and Hagan, J. 1978, 'Dependence and independence', in A. Curthoys and A. Marcus (eds), Who are Our Enemies? Racism and the Australian working class, Hale \& Iremonger in association with the Australian Society for the Study of Labour History, Neutral Bay, NSW, pp. 159-71.

Castle, R. and Hagan, J. 1998, 'Settlers and the state: the creation of an Aboriginal work force in Australia', Aboriginal History, vol. 22, pp. 24-35.

Commonwealth of Australia 2005, Budget 2004-2005, Department of Treasury, Canberra.

Cruze, B., Stewart, L. and Norman, S. 2005, Mutton Fish: The surviving culture of Aboriginal people and abalone on the South Coast of New South Wales, Aboriginal Studies Press, Canberra.

Dale Donaldson, S. 2006, Stories about the Eurobodalla by Aboriginal People: Eurobodalla Aboriginal Cultural Heritage Study. Stage two, Susan Dale Donaldson Environmental and Cultural Services, Eurobodalla Shire Council, Moruya, NSW. 
Dale Donaldson, S. 2008, Aboriginal Men and Women's Heritage: Eurobodalla, Eurobodalla Shire Council, Moruya, NSW.

Davidson, B. R. and Davidson, H. F. 1993, Legumes, the Australian Experience: The botany, ecology, and agriculture of Indigenous and immigrant legumes, Research Studies Press, Brisbane.

Elkin, A. P. 1951, 'Reaction and interaction: a food gathering people and European settlement in Australia', American Anthropologist, vol. 53, pp. 164-86.

Flanagan, F. 1845, 'Response to circular letter from Francis Flanagan. Report from the Select Committee on the Condition of the Aborigines with appendix', Minutes of Evidence and Replies to a Circular Letter, Government Printing Office, Sydney.

Goodall, H. 1982, The history of Aboriginal communities in NSW 1909-1939, Unpublished PhD thesis, Department of History, The Australian National University, Canberra.

Goodall, H. 1990, "Saving the children": gender and the colonisation of Aboriginal children in NSW, 1788 to 1990', Aboriginal Law Bulletin, vol. 2, no. 44, p. 9 .

Goodall, H. 1996, Invasion to Embassy: Land in Aboriginal politics in New South Wales, 1770-1972, Allen \& Unwin, Sydney.

Goulding, M. and Waters, K. 2005, Eurobodalla Aboriginal Cultural Heritage Study South Coast New South Wales. Stage one, Goulding Heritage Consulting Pty Ltd.

Lambie, J. 1846, 'Annual report on the state of the Aborigines for the year 1845, Commissioner of Crown Lands Lambie to Colonial Secretary Thomson', Historical Records of Australia, Series 1, p. 25.

Lambie, J. 1851, Annual report on the Aborigines of the Maneroo district for the year 1850, Commissioner Lambie to the Chief Commissioner, Crown Lands Office Cooma, Colonial Secretary Papers, Special bundles, Annual reports on state of the Aborigines in the various districts, 1851-53, State Records of New South Wales, Sydney.

Long, J. P. M. 1970, Aboriginal Settlements: A survey of institutional communities in eastern Australia, The Australian National University Press, Canberra.

McGregor, R. 2002, 'Assimilationists contest assimilation: T. G. H. Strehlow and A. P. Elkin on Aboriginal policy', Journal of Australian Studies, vol. 75, pp. 43-50. 
Manning, C. 1852, 'Report on the state of the Aborigines in the Maneroo district', Commissioner Manning, 23 March 1852, Colonial Secretary Papers, Special bundles, Annual Reports on State of the Aborigines in the Various Districts, 1851-53, State Records of New South Wales, Sydney.

Morris, B. 1985, 'Cultural domination and domestic dependence: the Dhan-Gadi of New South Wales and the protection of the state', Canberra Anthropology, vol. 8, nos 1-2, pp. 87-115.

Morris, B. 1989, Domesticating Resistance: The Dhan-Gadi Aborigines and the Australian state, Berg, New York and Oxford.

Oldrey, W. 1842, Return of Aboriginal natives taken at Broulee the 6th day of May 1842, Colonial Secretary special bundles: Aborigines 1837-44, Papers dealing with the issue of blankets, and including returns of the native population in the various districts, State Records of New South Wales, Sydney.

Organ, M. 1990, A Documentary History of the Illawarra and South Coast Aborigines, Aboriginal Education Unit, Wollongong University, NSW.

O'Toole, C. 1997, Beyond Bodalla: Recollections from my life, Moruya and District Historical Society, NSW.

Read, P. 1982, The Stolen Generations: the removal of Aboriginal children in New South Wales 1883 to 1969, Occasional Paper No. 1, New South Wales Ministry of Aboriginal Affairs, Sydney.

Rose, C. 1923, 'Recollections of the early days of Moruya', Journal and Proceedings of the Royal Australian Historical Society, p. 8.

Rose, D. B. 1990, Gulaga: A report on the cultural significance of Mt Dromedary to Aboriginal people, Forestry Commission of NSW and NSW National Parks and Wildlife Service, Hurtsville, NSW.

Rowse, T. 1998, White Flour, White Power: From rations to citizenship in Central Australia, Cambridge University Press, Melbourne.

The Bodalla Company 1958-62, Wages and summary cards for bean and pea picking, Noel Butlin Archives Centre, Canberra.

Trenchard, H. 1904, Aborigines Protection Board. Report for the year 1903, Second Session, Legislative Assembly of New South Wales, Sydney.

Trenchard, H. 1911, Letter of report from Mr. H. Trenchard to the Chairman, Aborigines Protection Board, 18th August 1911, as an attachment to a letter 
from the Secretary of the Aborigines Protection Board to the Under Secretary of the Department of Public Instruction, 8th September 1911, Wallaga Lake School File 1876-1939, State Records of New South Wales, Sydney.

Whiteford, D. 1985, An Economic History of the Bodalla Company 1900 to 1920. Student research essays in economic history, Department of Economic History, Faculty of Economics and Commerce, The Australian National University, Canberra. 